https://doi.org/10.19195/0524-4544.329.12

\title{
SŁAWOMIR FUNDOWICZ
}

ORCID: 0000-0001-5305-8239

Katolicki Uniwersytet Lubelski Jana Pawła II slawomir.fundowicz@kul.pl

\section{Przedsiębiorca w świetle personalistycznej koncepcji administracji publicznej}

\begin{abstract}
Abstrakt: W XIX wieku została zapoczątkowana myśl personalistyczna. Dla porządku społecznoprawnego największe znaczenie mają poglądy Emmanuela Mouniera (1905-1950) i Jacques'a Maritaina (1882-1973). Pierwszy z nich stwierdził, że osoba ludzka to jedyna rzeczywistość, którą poznajemy, a zarazem tworzymy „od wewnątrz”. Jego zdaniem człowiek może znajdować się w relacjach osobowych i rzeczowych, ale tylko te pierwsze działają na jego korzyść. Z kolei Martain dążył do tego, aby personalizm przeniknął życie społeczne. Dostrzegał w człowieku dwa wymiary: człowieka jako jednostkę i człowieka jako osobę.

Osoba ludzka jest jednocześnie granicą prawa. Z myśli personalistycznej wypływa koncepcja praw człowieka wyrażona w Powszechnej deklaracji praw człowieka z 10 grudnia 1948 roku. W personalistycznej koncepcji administracji publicznej chodzi o to, aby rozpisać na czynniki pierwsze zasadę, według której człowiek jako jednostka jest podporządkowany państwu, ale jako osoba nad nim góruje.

Personalizm odróżnia się od indywidualizmu tym, że człowiek w pełni realizuje się wśród innych ludzi, tworząc wspólnoty i społeczności. Spośród konsekwencji administracyjnoprawnych personalizmu można wskazać na zasadę pomocniczości, z której wynika zasada zaufania państwa do obywatela, w tym do przedsiębiorcy, oraz zasadę solidarności społecznej. Realizacją ustawową zasady zaufania państwa do obywatela są zasady ogólne Prawa przedsiębiorców (zasada domniemania uczciwości przedsiębiorcy, zasada przyjaznej interpretacji przepisów prawa, zasada rozstrzygania wątpliwości faktycznych na korzyść przedsiębiorcy). Z zasady zaś solidarności wynika obowiązek działania przedsiębiorcy na rzecz dobra wspólnego.

Przykładem praktycznego podejścia do spraw gospodarczych mogą być rozwiązania proponowane przez Talmud, w których w odniesieniu do działalności handlowej uwalnia się jednostki od niepotrzebnych interwencji społeczeństwa, ufając uczciwości jego członków, a także uznając społeczeństwo za wspólnotę osób, dopuszcza się możliwość arbitrażu.
\end{abstract}

Słowa kluczowe: personalizm, przedsiębiorca, administracja publiczna, zasada pomocniczości, zasada solidarności społecznej. 


\section{Założenia personalistycznej koncepcji administracji publicznej}

Myśl personalistyczna została zapoczątkowana w drugiej połowie XIX wie$\mathrm{ku}^{1}$. Głównym jej ośrodkiem był wtedy uniwersytet w Bostonie ${ }^{2}$. Był to wówczas personalizm indywidualistyczny, oparty na podstawach teologii protestanckiej ${ }^{3}$. Z tego okresu warto przywołać przytoczone przez Walta Whitmana zdanie Abrahama Lincolna: „Rząd z ludzi, przez ludzi, dla ludzi” jako dobrze oddające sposób myślenia personalistycznego ${ }^{4}$.

Poglądy personalistyczne pojawiały się $\mathrm{w}$ różnych środowiskach narodowych, w związku z czym można wyróżnić personalizm francuski, niemiecki, a także polski ${ }^{5}$. Łączyły się one także z różnymi kierunkami filozoficznymi, przez co można wyodrębnić personalizm filozoficzno-religijny (Pierre Teilhard de Chardin, Nikołaj Bierdiajew), fenomenologiczny (Max Scheler, Edith Stein), egzystencjalny (Karl Jaspers, Gabriel Marcel), a także neotomistyczny (Jacques Maritain) ${ }^{6}$.

Bez wątpienia w odniesieniu do porządku społeczno-prawnego największe znaczenie mają poglądy Emmanuela Mouniera i Jacques’a Maritaina.

Emmanuel Mounier (1905-1950) stwierdził, że osoba nie jest bytem, nie jest też przedmiotem. Jest ona w człowieku właśnie tym, co nie może być traktowane jako przedmiot. Osoba to jedyna rzeczywistość, którą poznajemy, a zarazem tworzymy „od wewnątrz”. Nigdy nie jest dana, lecz zawsze obecna. Osoba ludzka nie redukuje się ani do zespołu cech dających się nazwać i określić, ani też do pewnej szczególnej kombinacji ról społecznych ${ }^{7}$. Życie osobowe powoduje osamotnienie człowieka. Niepowtarzalność zaś bytu osobowego uniemożliwia komunikację treści życia osobowego. Mounier dążył jednak do przełamania owej izolacji, twierdząc, że życie osobowe możliwe jest tylko we wspólnocie. Dlatego też parafrazuje myśl kartezjańską, głosząc Amo ergo sum, a więc — to miłość jest

1 Pierwszą osobą, która zastosowała określenie „personalizm” do filozofii, był — według J.M. Burgosa - Ramón de Campoamor, który w 1855 roku opublikował pracę zatytułowaną El personalismo. Apuntes para una filosofia; zob. J.M. Burgos, Personalizm, Warszawa 2010, s. 63-64.

2 Por. B. Gacka, Personalizm amerykański, Lublin 1996.

3 C. Głombik, Osoba i kultura w filozoficznej wizji Jacques'a Maritaina, [w:] Filozofia XX wieku, red. Z. Kuderowicz, Warszawa 2002, s. 246.

4 W. Whitman, Demokracja i personalizm, Lublin 1994, s. 13.

5 Ten ostatni najpełniej zrealizowany został przez W. Granata (por. idem, Osoba ludzka. Próba definicji, Sandomierz 1961; idem, U podstaw humanizmu chrześcijańskiego, Poznań 1976) oraz Karola Wojtyłę (por. idem, Osoba i czyn i inne studia antropologiczne, Lublin 1994).

6 Por. C. Bartnik, Personalizm, Lublin 1995.

7 T. Płużański, Emmanuel Mounier — twórca personalizmu, [w:] Filozofia XX wieku..., s. 268. 
dowodem istnienia osobowego, co najmniej tak przekonującym jak myślenie, $\mathrm{i}$ to miłość zapewni rozwiązanie dylematu izolacji i komunikacji międzyosobowej ${ }^{8}$.

Wśród relacji międzyludzkich Mounier odróżnia relacje rzeczowe i osobowe. Te drugie są nacechowane miłością, dostrzeganiem i uznaniem w drugim człowieku osoby, działaniem na korzyść jej rozwoju, uznaniem jej niezastępowalności. Tymczasem pierwsze, dominujące w realnym świecie, wyznaczają drogę do depersonalizacji, gdyż sprowadzają jednostkę do jej funkcji społecznej, w której może być łatwo zastąpiona ${ }^{9}$.

Z kolei Jacques Maritain (1882-1973) najpełniej przedstawił swoją koncepcję personalistyczną w swojej pracy Humanizm integralny z 1936 roku $^{10}$. Filozof ten dążył do tego, by personalizm przenikał życie społeczne, by określał prawdziwie chrześcijańską myśl oraz praktykę polityczną, a także by techniczna racjonalizacja sposobów życia publicznego stale miała na uwadze humanizm osoby oraz demokratyczną naturę nowego, zhumanizowanego społeczeństwa przyszłości ${ }^{11}$. Personalizm Maritaina opierał się na tezie, że natura ludzka jest bytem złożonym, składającym się z tego, co jest w nim jednostkowe, indywidualne, oraz tego, co stanowi o jego duchowym, osobowym wymiarze. Człowiek — przez swoją fizyczną strukturę, dany mu element cielesności wraz z wszystkimi wynikającymi z tego społecznymi powinnościami, uwikłaniami i następstwami - jest jednostką i przejawem przyrodniczego gatunku, do którego przynależy, wchodząc wraz z nim w skład wielkiego materialnego porządku świata i rządzących nim praw. Człowiek to jednak nie tylko jednostka fizyczna, lecz także osoba. W tym wymiarze charakteryzuje go życie duchowe, właściwe są mu wewnętrzne akty wyborów, dążeń, intelektualnych samookreśleń, pozwalające mu wykroczyć poza świat przyrody i kultury, a ukazujące jego niepowtarzalny status osoby jako ostoi moralności i godności ${ }^{12}$. Maritain podkreślał: „Człowiek jest w całości jednostką i również w całości osobą"13. Są to dwa aspekty jednego i tego samego bytu ludzkiego, z tym że osobie przysługuje nadrzędność i prymat bezwzględny, podczas gdy świat jednostki, natury i kultury odgrywa rolę instrumentalną wobec trwania osoby ${ }^{14}$.

8 Ibidem, s. 269-270.

9 Ibidem, s. 271-272.

10 Praca ta ukazała się w języku polskim dopiero w 1960 roku - J. Maritain, Humanizm integralny. Zagadnienia doczesne i duchowe nowego świata chrześcijańskiego, Londyn 1960, Warszawa 1981.

11 C. Głombik, op. cit., s. 247.

12 Ibidem, s. 247-248.

13 J. Maritain, Osoba ludzka i społeczeństwo, [w:] idem, Pisma filozoficzne, Kraków 1988, s. 327.

14 C. Głombik, op. cit., s. 248-249. 


\section{Pojęcie osoby jako podstawowe założenie personalistycznej koncepcji administracji publicznej}

Ostateczną granicą prawa jest osoba ludzka. Powszechnie znane przykłady odnoszące się zarówno do czasów biblijnych ${ }^{15}$, jak i helleńskich ${ }^{16}$, a także nowożytnych uświadamiają, że nie da się zawłaszczyć całego życia człowieka. Gdy zestawimy suwerenności człowieka z suwerennością państwa oraz spróbujemy ustalić ich wzajemne zależności i pierwszeństwa, mamy tylko dwie możliwości: albo pierwotnie suwerenem jest państwo, a osoba ludzka zyskuje jakieś uczestniczenie w suwerenności od państwa, albo odwrotnie — pierwotnie suwerenem jest ludzka osoba, która w pewnym zakresie udziela praw suwerena państwu. Zwykle suwerenność wiąże się z państwem. Takie stanowisko trzeba jednak zakwestionować. To prymat suwerenności osoby jest bowiem związany z samym celem istnienia państwa i racją bytu społeczeństwa, jakim jest tak zwane dobro wspólne ${ }^{17}$.

Klasyczną definicję osoby sformułował rzymski filozof i mąż stanu Anicius Manlius Boethius (480-524). Według niego osobą jest indywidualna substancja natury rozumnej ${ }^{18}$. Boethius podkreśla przy tym indywidualność i szczególność osoby. To otworzyło drogę dla średniowiecza, które określi osobę jako absolutną osobność i szczególność, jako bycie indywiduum dla siebie, izolowane od wewnątrz od wszelkich innych bytów ${ }^{19}$. Ważne dopowiedzenia do tej definicji można odnaleźć u Ryszarda od świętego Wiktora pod Paryżem $(+1173)^{20}$ i u Tomasza z Akwinu (1224-1274) ${ }^{21}$. Te tezy zostały niejako na nowo odkryte w końcu XIX wieku i doprowadziły do wypracowania współczesnej koncepcji osoby, której przypisuje się następujące cechy: poznanie intelektualne, miłość, wolność, podmiotowość wobec prawa, zupełność oraz godność ${ }^{22}$.

Jednym z największych osiągnięć myśli personalistycznej stała się Powszechna deklaracja praw człowieka przyjęta 10 grudnia 1948 roku przez Zgromadzenie Ogólne Narodów Zjednoczonych. Powszechna deklaracja praw człowieka jest zbiorem praw pojętych nie jako lex - jako jakaś norma prawna, lecz jako ius - uprawnienie, które człowiek zawsze posiada i od nikogo uprawnień tych nie nabywa. Z natury rzeczy prawo jako uprawnienie stoi przed prawem rozumianym jako norma prawna, która ma kierować ludzkimi czynami w danej społeczno-

15 Można przywołać przykład Tobiasza czy Daniela w czasach babilońskich, a w jeszcze większym wymiarze także Estery.

16 Klasycznym przykładem jest tutaj Antygona.

17 A. Krąpiec, Suwerenność - czyja?, Lublin 1996, s. 41.

18 „Persona est naturae rationalis (choć w ostatnich wydaniach krytycznych jest: rationabilis) individua substantia" - Anicius Manlius Boethius, Liber de persona, III, PL 64, 1343C.

19 C. Bartnik, Personalizm, Lublin 2000, s. 87.

20 Ibidem, s. 88-89.

21 Ibidem, s. 90-92.

22 A. Krąpiec, Czlowiek i prawo naturalne, Lublin 1993, s. 133-142. 
ści. Zanim pojawi się bowiem jakakolwiek norma postępowania, już zastajemy $\mathrm{w}$ świecie realnie istniejących ludzi prawo, które z człowiekiem jest nieodzownie związane ${ }^{23}$.

Maritain, dostrzegając źródła praw człowieka w prawie naturalnym i niezbywalnej godności człowieka, podkreślał, że jednostka ludzka jest w jakiś sposób transcendentna wobec państwa i jego doraźnych zadań, co jednak nie usprawiedliwia zachowań aspołecznych. Odpowiedzialność i obowiązki wobec społeczeństwa nie naruszają w żaden sposób uprawnień człowieka jako osoby. Maritain wyróżnił trzy grupy praw człowieka: fundamentalne, polityczne i ekonomiczno-społeczne. Do pierwszych zaliczył prawo do istnienia i życia, prawo do wolności oraz wyboru własnej drogi życiowej, prawo do respektowania przez innych integralności cielesnej, prawo do własności prywatnej, prawo do założenia rodziny. Podkreśla przy tym potrzebę łączenia indywidualnego i społecznego ich profilu. Druga grupa praw określa zakres uprawnień człowieka w ramach wspólnoty polityczno-społecznej. Trzecią zaś tworzą prawa pracownicze ${ }^{24}$.

Personaliści odróżniali pojęcia „indywiduum” oraz „osoba”. Zauważyli, że jednostkowość człowieka jest funkcją materii i dlatego nie wyodrębnia go w stosunku do grupy społecznej, ale podporządkowuje tej grupie na wzór podporządkowania komórki biologicznej całemu organizmowi. Natomiast człowiek jako osoba góruje nad społecznością i to ona powinna być jemu przyporządkowana ${ }^{25}$. Również w prawie administracyjnym należy dążyć do realizacji formuły, według której człowiek jako jednostka jest państwu powinien, natomiast jako osoba jest wolny od państwa. Nie jest to reguła łatwa do rozpisania na czynniki pierwsze w perspektywie konkretnych sytuacji prawnych i stanów faktycznych, zwłaszcza gdy weźmie się pod uwagę ciągle trwające przeobrażenie rzeczywistości społeczno-gospodarczej, za którym stosunkowo wolno idą zmiany świadomości społecznej, także wśród tych, którzy tworzą i wykonują normy prawne ${ }^{26}$.

\section{Między osobą a wspólnotą}

Mounier, analizując istotę personalizmu, podkreślił:

Personalizm nie jest nową postacią indywidualizmu. Przeciwnie, dążenie do rozwoju życia osobowego i dążenie indywidualistyczne są zorientowane w przeciwnych kierunkach. Indywidualizm ujmuje ludzkie ,ja” jako rzeczywistość izolowaną, z natury rzeczy oddzieloną od świata i od innych ,ja”. [...] Osoba ludzka nie przeciwstawia się pojęciu „my” — to „my” ją utwierdza i wzbo-

23 A. Krąpiec, Suwerenność..., s. 131.

24 J. Maritain, Człowiek i państwo, Kraków 1993, s. 83-115; por. S. Kowalczyk, Wprowadzenie do filozofii J. Maritaina, Lublin 1992, s. 70-72.

25 A. Krąpiec, Ja - czlowiek, Lublin 1991, s. 320.

26 M. Zdyb, Publiczne prawo gospodarcze, Kraków 1998, s. 115-116. 
gaca; przeciwstawia się natomiast formie bezosobowej, zacierającej poczucie odpowiedzialności i tyranizującej człowieka. [...] Człowiek-osoba nie jest człowiekiem rozproszonym — jest on otoczony, wciągnięty i powołany. Puszczenie w niepamięć tej prawdy jest wielkim grzechem Zachodu. [...] Tak więc filozofia osoby nie skłania człowieka do izolacji, do przeżuwania własnych problemów do ucieczki od świata. Przeciwnie, skłania do zaciekłej walki i aktywnej służby ${ }^{27}$.

W podobnym duchu wypowiada się Maritain, gdy stawia tezę, że epoka nowożytna grzeszy przesadnym indywidualizmem. Potwierdzeniem tego jest trojaka próba reformy: religijnej Lutra, filozoficznej Descartes'a i pedagogicznej Rousseau. Wszyscy trzej bronili „świętych praw jednostki”, a mimo to człowiek współczesny poddany jest bezlitosnemu panowaniu „Państwa, Pieniądza, Opinii" ${ }^{28}$. Osoba ludzka jest swoistą całością, ale otwartą na innych ludzi. Maritain uznaje naturalność i nieodzowność istnienia człowieka w społeczeństwie. Dzieje się to z dwóch powodów — pierwszy to konieczność międzyosobowej interakcji, związana z naturalnym dla człowieka-osoby pragnieniem wymiany posiadanych niższych i wyższych wartości; drugi — różnorodne braki, jakich doświadcza człowiek w zakresie swej materialności i życia biologicznego 29 .

Dla Maritaina wspólnota jest bardziej dziełem natury, natomiast społeczeństwo w większym stopniu efektem rozeznania intelektu i decyzji woli. Wspólnota jest więc w zasadzie stwierdzeniem stanu faktycznego, zaistniałego w sposób naturalno-spontaniczny. Sam jednak Maritain, mimo nie zawsze klarownych i jednoznacznych wypowiedzi, bardziej cenił kategorię społeczeństwa, widząc w nim wyższą formę życia społecznego ${ }^{30}$.

Mounier swoją filozofię nazwał wprost personalizmem wspólnotowym. Osoba, której nadał prymat, była rzeczywistością duchową, pozostającą w istotnych relacjach z innymi osobami. Myśliciel ten odróżniał także wspólnotę od społeczności. Przez społeczność rozumiał grupę, którą tworzą osoby. Nie każde połączenie osób tworzy jednak wspólnotę. Istnieją grupy, w których przeważa depersonalizacja, anonimowa masa. I takie grupy, pod wpływem przekonań Martina Heideggera, Mounier nazywa społecznościami. Istnieją więc społeczności oparte na koleżeństwie i przyjaźni, społeczności prawników itp. Choć mają one znaczenie, to żadna z nich nie osiąga poziomu wspólnoty. We wspólnocie należy bowiem osobę traktować absolutnie poważnie. W drugim człowieku trzeba dostrzec ,ty”, zobaczyć bliźniego i wejść z nim w relację w taki sposób, aby stworzyć „my”. Wspólnota powstaje wtedy, gdy na drugiego człowieka patrzy się jak na bliźniego, a nie jak na kogoś podobnego, bo należącego do tego samego gatunku ${ }^{31}$.

\footnotetext{
27 E. Mounier, Co to jest personalizm? Oraz wybór innych prac, Warszawa 1960, s. 200-202.

28 J. Maritain, Trzej reformatorzy: Luter, Decartes, Rousseau, Warszawa 1939, s. 30.

29 S. Kowalczyk, op. cit., s. 59-60.

30 Ibidem, s. 61-62.

31 J.M. Burgos, op. cit., s. 70-71.
} 


\section{Konsekwencje personalistycznej koncepcji administracji publicznej dla publicznego prawa gospodarczego}

Z przedstawionych założeń wynika wiele wniosków, które prowadzą do praktycznych rozwiązań również w sferze gospodarczej. Wystarczy przyjrzeć się dwóm prostym konsekwencjom: zasadzie pomocniczości (i wynikającej z niej zasadzie zaufania państwa do obywatela, w tym do przedsiębiorcy) oraz zasadzie solidarności społecznej.

Konstytucja Rzeczypospolitej Polskiej z 2 kwietnia 1997 roku w preambule określa zasadę pomocniczości obok poszanowania wolności i sprawiedliwości, współdziałania władz oraz dialogu społecznego jako podstawę jej przepisów ${ }^{32}$. Zasada ta rozumiana jest w sposób określony przez katolicką naukę społeczną, zawartą zwłaszcza w encyklice Piusa XI Quadragesimo anno i encyklice Jana XXIII Mater et magistra. W Mater et magistra papież napisał bowiem:

Władze państwowe mogą nakazywać tylko to, co jak można przypuszczać, prowadzi do powszechnego użytku obywateli. Dbając więc o dobro całego kraju, władze państwowe powinny troszczyć się usilnie o równomierny w miarę możności rozwój rolnictwa, przemysłu i usług. Należy przy tym trzymać się zasady, że mieszkańcy terenów opóźnionych w rozwoju powinni sami czuć się głównymi twórcami postępu w dziedzinie gospodarczej, społecznej i kulturalnej. Ci bowiem są godni miana obywateli, którzy sami wnoszą główny wkład w dzieło poprawy swego losu. Trzeba, aby do równomiernej rozbudowy gospodarczej w skali krajowej przyczyniali się także w miarę możliwości właściciele kapitału i przedsiębiorstw. Dlatego też — w myśl „zasady pomocniczości” — władze państwowe powinny wspierać i pobudzać inicjatywę osób prywatnych, a to w ten sposób, że będą, jeśli się to tylko okaże możliwe, pozwalać im na wykonywanie zaplanowanych zadań ${ }^{33}$.

Istnieją więc obowiązki państwa wobec jednostki, o ile zaspokojenie jej potrzeb przekracza jej możliwości, a jeszcze ściślej — jest to zobowiązanie państwa w stosunku do mniejszych wspólnot, o ile nie zostanie przekroczona ich zdolność do świadczeń ${ }^{34}$. Nie należy jednak rozumieć tej zasady w taki sposób, że państwo może działać tylko jako pomoc. Często konieczne będzie bowiem uzupełniające działanie państwa. Może też zostać dopuszczony system dualistyczny, względnie paralelna działalność prywatna i publiczna ${ }^{35}$.

Zasada pomocniczości jest równocześnie zasadą ontologiczną (zasadą bytu społecznego), prawną i moralną. Każda społeczność ma charakter służebny i celowy, jej celem jest służyć człowiekowi przez zaspokajanie pewnej kategorii jego potrzeb. Z zasady pomocniczości wynika też, że źródłem wszelkich praw społecz-

32 Preambuła Konstytucji Rzeczypospolitej Polskiej z dnia 2 kwietnia 1997 roku (Dz.U. Nr 78, poz. 483).

33 Jan XXIII, Mater et magistra, nr 151-152.

34 N. Achterberg, Algemeines Verwaltungsrecht. Ein Lehrbuch, Heidelberg 1986, s. 108.

35 Ibidem, s. 52. 
nych są prawa osobowe. Człowiek szuka pomocy społeczności, tylko wówczas i tylko w tym zakresie, w jakim nie może sam spełniać swych zadań życiowych. To samo dotyczy każdej społeczności, która odwołuje się do społeczności wyższych i większych, tylko gdy nie może spełniać wszystkich zadań wyznaczonych jej przez potrzeby jej członków. Z kolei społeczność wyższa musi szanować prawa społeczności niższych, tak samo jak każda społeczność winna szanować prawa człowieka - naruszając bowiem te prawa, wyższe społeczności uniemożliwiają społecznościom niższym i człowiekowi spełnienie ich naturalnych zadań.

Wreszcie zasada pomocniczości wskazuje na hierarchię wartości moralnych. Źródłem dobra ogólnego każdej społeczności jest dobro osobowe. W ten sposób dobra poszczególnych społeczności są wzajemnie powiązane, ale też wzajemnie zhierarchizowane, odpowiednio do zakresu dobra osobowego, które reprezentują i liczby osób, które są przez to dobro reprezentowane. $\mathrm{Z}$ zasady pomocniczości wyprowadza się trzy zasady organizacji życia społeczno-gospodarczego: zasadę organicznej budowy społeczności państwowej, zasadę decentralizacji władzy publicznej oraz zasadę demokracji ${ }^{36}$.

Ta analiza prowadzi do zasady zaufania organów państwa do obywateli. Odblask tej zasady można zauważyć choćby w zasadzie uwzględniania urzędu słusznego interesu stron i interesu społecznego i wynikającego z niej obowiązku harmonizowania owych interesów ${ }^{37}$. Trzeba zauważyć, że nie chodzi tutaj o budowanie zaufania do organów państwa, ale o postawę zwróconą w odwrotnym kierunku — to organy państwa (czy organy administracji publicznej) mają wypracowywać w swoim działaniu zaufanie do człowieka, do obywatela, do przedsiębiorcy, stwarzając możliwość swobodnego działania i wspierając tę swobodę zarówno środkami władczymi, jak i gamą środków z zakresu administracji świadczącej (na przykład w odniesieniu do mikro-, małych i średnich przedsiębiorców), a także wypracowanymi ogólnymi zasadami zachowania się. W tym kontekście trzeba przytoczyć zasady ogólne Prawa przedsiębiorców, a wśród nich zasadę domniemania uczciwości przedsiębiorcy, zasadę przyjaznej interpretacji przepisów prawa oraz zasadę rozstrzygania wątpliwości faktycznych na korzyść przedsiębiorcy. Wydaje się, że w obszarze publicznego prawa gospodarczego udało się, choćby częściowo, wprowadzić jego zasady ogólne, z których treści można z kolei wywieść wniosek, że administracja gospodarcza (w rozumieniu wszelkich organów administracji publicznej odnoszących się w jakikolwiek sposób do przedsiębiorcy) działa w zaufaniu do przedsiębiorcy.

Zgodnie z preambułą Konstytucji Rzeczypospolitej Polskiej prawa podstawowe dla państwa oparte są między innymi na dialogu społecznym, a wszyscy, którzy będą je stosować, mają to czynić, dbając o zachowanie obowiązku człowieka solidarności z innymi. W ten sposób do polskiego porządku prawnego zo-

36 C. Strzeszewski, op. cit., s. 510-515.

37 Por. art. 7 k.p.a. 
stała wprowadzona zasada solidarności. W katolickiej nauce społecznej wymienia się ją obok pomocniczości jako podstawową zasadę organizacji życia społecznego. Zasada solidarności porządkuje działalność jednostek, zwracając ją ku dobru społecznemu. Ta zasada utożsamiana jest z zasadą dobra wspólnego i można ją zdefiniować jako uporządkowaną zgodę w dążeniu do dobra wspólnego ${ }^{38}$. Dobro wspólne trzeba rozumieć jako cel dążenia ludzkiego (finalistyczna koncepcja dobra). Dobrem można nazwać ten przedmiot ludzkiego działania, który może stać się celem jednostkowym każdego osobowego dążenia ${ }^{39}$. W koncepcji dobra wspólnego można wyróżnić trzy elementy: poszanowanie osoby jako takiej; dobrobyt, czyli rozwój dóbr duchowych i ziemskich społeczności; oraz pokój, czyli trwałość i bezpieczeństwo sprawiedliwego porządku ${ }^{40}$.

Przeciwny kierunek myślenia o dobru wspólnym reprezentują zwolennicy indywidualistycznego liberalizmu. Ta doktryna ma swoje korzenie w twórczości i sformułowaniach J.J. Rousseau. Podstawowym założeniem jest, że każdy człowiek rodzi się wolny. Dla Rousseau znaczy to tyle, że każdy cieszy się stanem wolności, który ma od urodzenia. W Umowie społecznej filozof pisze więc: „Znaleźć formę zrzeszania, która by broniła i chroniła całą siłą wspólną osobę i dobra każdego członka i przy której każdy, łącząc się ze wszystkimi, słuchałby jednak tylko siebie i pozostał wolnym jak poprzednio"41.

W ten sposób przyjęto mit o powszechnej zgodzie, w myśl której każdy do pewnego stopnia rezygnuje ze swych suwerennych praw i zrzesza się w związku społecznym kierowanym przez prawo, które nie jest produktem rozumu, lecz rezultatem woli liczby jednostek ludzkich i dlatego występująca w imię liczby ludzi władza może drugiemu człowiekowi rozkazywać. Siłą rzeczy niemożliwe jest tutaj realizowanie żadnego dobra wspólnego. Demokracja indywidualistyczno-liberalistyczna przeradzała się w rządy albo jednej partii całkowicie rozwiązującej wszelkie trudności, albo jednej rasy, albo jednego narodu, albo jednego „opatrznościowego" człowieka — wodza ${ }^{42}$.

Zasada solidarności wprowadza w publiczne prawo gospodarcze obowiązek działania przedsiębiorcy na rzecz dobra wspólnego. Oczywiście takie obowiązki muszą być wprowadzane z uwzględnieniem zasady proporcjonalności. Ten sposób myślenia jest w zasadzie ugruntowany w polskiej myśli prawniczej, ale wciąż wydaje się niedoceniany. Można przytoczyć tutaj fragment uzasadnienia wyroku Trybunału Konstytucyjnego z 5 listopada 1997 roku w sprawie wprowadzenia obowiązków właścicieli nieruchomości w ustawie z dnia 13 września 1996 roku o utrzymaniu czystości i porządku w gminach: „Przepis w swej treści jest wyra-

38 C. Strzeszewski, op. cit., s. 516.

39 A. Krąpiec, Czlowiek i prawo..., s. 164-171.

40 Konstytucje Rzeczypospolitej oraz komentarz do Konstytucji RP z 1997 r., red. J. Boć, Wrocław 1998, s. 16-17.

41 J.J. Rousseau, Umowa społeczna, Kęty 2002, s. 19.

42 A. Krąpiec, Człowiek i prawo..., s. 171-172. 
zem przyjętego od dawna poglądu, zgodnie z którym z prawa własności wynikają także określone obowiązki społeczne"43.

\section{Praktyczne zastosowanie na przykładzie żydowskiego Talmudu}

Talmud może wskazać pewien kierunek myślenia prawnogospodarczego. Posłużmy się dwoma przykładami:

Mar Zutra i Raw Adda Sabba, synowie Rawa Mariego bar Isur, dzielili między siebie majątek. Przyszli do Rawa Asziego i powiedzieli, że Tora nakazuje, by ,zeznaniem dwu świadków ustanowiona była sprawa prawna" (Pwt 19, 15). Czy to stosuje się tylko do przypadków, gdy jedna osoba chce się wycofać z umowy prawnej, w którą weszła z inną osobą i nie może tego zrobić, ponieważ świadkowie zaświadczą na rzecz oryginalnej umowy? Jeśli taki jest powód, to nie uczyni tego. Lub, być może, żadna w ogóle sprawa prawna nie jest ważna bez obecności świadków. Raw Aszi odpowiedział im, że świadków dobiera się tylko wtedy, gdy chodzi o stronę przeczącą umowie ${ }^{44}$.

Synowie Rawa Mariego bar Isur zadają fundamentalne pytanie o cel prawa wymagającego świadków w postępowaniu kontraktowym, na które Raw Aszi (cieszący się wielkim autorytetem $\mathrm{w}$ zakresie prawa talmudycznego) odpowiedział, że w postępowaniu handlowym nie ma wymagania obecności dwóch świadków, choć zwyczajowo ich obecność ma miejsce. Trzeba zauważyć, że świadkowie byli w tym wypadku przedstawicielami społeczeństwa, a więc ostatecznie chodzi o problem udziału społeczeństwa w prywatnych umowach zawieranych przez jednostki.

Problem ten można przedstawić jeszcze inaczej — czy osoba jest cząstką społeczeństwa (a wtedy społeczeństwo, w osobach świadków, powinno być obecne przy umowach dwóch stron), czy też osobą jest się niezależnie od społeczeństwa (a wtedy społeczeństwo może odgrywać tylko rolę pośrednika w sporach między stronami, osoby bowiem są w społeczeństwie, ale nie są jego własnością). Tekst talmudyczny wyraźnie opowiada się za wzajemną współpracą i zaufaniem. Zgodnie $\mathrm{z}$ tą interpretacją przynajmniej w dziedzinie handlowej jednostki nie powinny być nękane niepotrzebnymi interwencjami społeczeństwa, które musi mieć zaufanie do podstawowej uczciwości swoich członków.

D. Novak podsumowuje tę dyskusję następująco: „Bez takiego zaufania pozostają tylko dwie możliwości: anarchia albo tyrania. Bez zaufania społeczeństwo musi, innymi słowy, stać się nieobecne, albo wszechobecne". Warto jednak

43 Wyrok TK z dnia 5 listopada 1997 roku, sygn. K. 22/97, Dz.U. Nr 140, poz. 941, zob. OTK ZU 3-4/1997, poz. 41. Trzeba odczytywać ten wyrok w kontekście zasady społecznej gospodarki rynkowej, która opiera się na wolności działalności gospodarczej, własności prywatnej oraz solidarności, dialogu i współpracy partnerów społecznych (art. 20 Konstytucji).

44 Qidduszin, 65b. 
zauważyć, że w odniesieniu do umów małżeńskich ten sam tekst talmudyczny nalega na obecność świadków jako podstawy ważności umowy, uznając rodziny za ważniejszy komponent społeczeństwa niż jednostki mające dobra i obracające nimi. Społeczeństwo ma więc troszczyć się bardziej o status niż o kontrakty ${ }^{45}$.

Inny przykład dotyczy legalności arbitrażu:

Rabbi Eliezer, syn rabbiego Jose Galilejczka, powiedział, że zabronione jest być arbitrem [...], ale niech prawo przeszyje górę, jak mówi Pismo: ,jest to sąd Boży” (Pwt 1, 17) [...]. Rabbi Jozue ben Korhah powiedział, że jest zalecane stosować arbitraż, jak mówi Pismo: ,prawdziwy i pokojowy sąd wydacie w bramach waszych" $(\mathrm{Za} 8,16)$. Ale czyż nie jest tak, że tam, gdzie jest sprawiedliwość, tam nie ma pokoju, a gdzie jest pokój, tam nie ma sprawiedliwości? Jaki więc rodzaj sprawiedliwości zawiera w sobie pokój? To jest arbitraż ${ }^{46}$.

Tym razem chodzi o relację prawa do społeczności - czy społeczeństwo istnieje ze względu na prawo, czy prawo istnieje ze względu na społeczeństwo. Odpowiedź trzeba uzależnić od tego, co uważa się za istotną funkcję społeczeństwa — jeśli społeczeństwo istnieje po to, aby być zwierciadłem wyższego porządku i wprowadzać go w życie na ziemi, to trzeba się zgodzić z Eliezerem; jeśli natomiast społeczeństwo jest wspólnotą osób, to wtedy należy przyjąć stronę rabbiego Jozuego ben Korhah.

Co oczywiste, arbitraż wymaga od człowieka w większym stopniu niezależnego rozumowania niż formalny osąd oparty na prawie pisanym. Zdaniem D. Novaka późniejsza żydowska tradycja prawna skłaniała się ku poglądowi rabbiego ben Korhah ${ }^{47}$.

\section{Bibliografia}

Achterberg N., Algemeines Verwaltungsrecht. Ein Lehrbuch, Heidelberg 1986.

Bartnik C., Personalizm, Lublin 1995.

Burgos J.M., Personalizm, Warszawa 2010.

Gacka B., Personalizm amerykański, Lublin 1996.

Głombik C., Osoba i kultura w filozoficznej wizji Jacques'a Maritaina, [w:] Filozofia XX wieku, red.

Z. Kuderowicz, Warszawa 2002.

Granat W., Osoba ludzka. Próba definicji, Sandomierz 1961.

Granat W., U podstaw humanizmu chrześcijańskiego, Poznań 1976.

Konstytucje Rzeczypospolitej oraz komentarz do Konstytucji RP z 1997 r., red. J. Boć, Wrocław 1998.

Kowalczyk S., Wprowadzenie do filozofii J. Maritaina, Lublin 1992.

Krąpiec A., Człowiek i prawo naturalne, Lublin 1993.

Krąpiec A., Ja - czlowiek, Lublin 1991.

45 D. Novak, Talmud jako źródło refleksji filozoficznej, [w:] Historia filozofii żydowskiej, red.

D.H. Frank, O. Leaman, Kraków 2009, s. 87.

46 Sanhedrin, 6b.

47 D. Novak, op. cit., s. 88. 
Krąpiec A., Suwerenność — czyja?, Lublin 1996.

Maritain J., Człowiek i państwo, Kraków 1993.

Maritain J., Humanizm integralny. Zagadnienia doczesne i duchowe nowego świata chrześcijańskiego, Londyn 1960.

Maritain J., Osoba ludzka i społeczeństwo, [w:] idem, Pisma filozoficzne, Kraków 1988.

Maritain J., Trzej reformatorzy: Luter, Decartes, Rousseau, Warszawa 1939.

Mounier E., Co to jest personalizm? Oraz wybór innych prac, Warszawa 1960.

Novak D., Talmud jako źródto refleksji filozoficznej, [w:] Historia filozofii żydowskiej, red. D.H. Frank, O. Leaman, Kraków 2009.

Płużański T., Emmanuel Mounier — twórca personalizmu, [w:] Filozofia XX wieku, red. Z. Kuderowicz, Warszawa 2002.

Rousseau J.J., Umowa społeczna, Kęty 2002.

Whitman W., Demokracja i personalizm, Lublin 1994.

Wojtyła K., Osoba i czyn i inne studia antropologiczne, [w:] Człowiek i moralność, Lublin 1994.

Zdyb M., Publiczne prawo gospodarcze, Kraków 1998.

\section{An entrepreneur in the light of the personalist concept of public administration}

\section{Summary}

In the nineteenth century, personalistic thought was initiated. For the social and legal order, the views of Emmanuel Mounier (1905-1950) and Jacques Maritain (1882-1973) are the most important. The first stated that the human person is the only reality that we learn and create from within. A human may be in personal and material relations, but only the first of these work in his favor. Maritain strived for personalism to permeate social life. He saw in man two dimensions: man as an individual and man as a person. The human person is the limit of law. The concept of human rights expressed in the Universal Declaration of Human Rights of December 10th, 1948 flows from personalist thought. The personalist concept of public administration is about writing down the principle that man as an individual is subordinated to the state, but as a person he dominates over the state. Personalism differs from individualism in that man fully realizes himself among other people, creating communities. Among the administrative and legal consequences of personalism, one can point to the principle of subsidiarity, which implies the principle of state trust in the citizen, including the entrepreneur, and the principle of social solidarity. The statutory implementation of the state trust principle in the citizen are general principles of the Law of Entrepreneurs (principle of presumption of entrepreneur integrity, principle of friendly interpretation of legal provisions, principle of settling factual doubts in favor of the entrepreneur). The principle of solidarity implies the obligation of the entrepreneur to act for the common good. An example of a practical approach to economic matters may be the solutions proposed by the Talmud, in which, in relation to commercial activities, individuals are freed from unnecessary public intervention, trusting the integrity of its members, and, recognizing society as a community of persons, the possibility of arbitration is allowed.

Keywords: personalism, entrepreneur, public administration, principle of subsidiarity, principle of solidarity. 